\title{
Archiving of Deep Percolation Models, Data Files, and Calculated Recharge Estimates for the Columbia Plateau Regional Aquifer System, Washington, Oregon, and Idaho
}

A contribution of the Regional

Aquifer-System Analysis Program

U.S. GEOLOGICAL SURVEY

Open-File Report 88-186
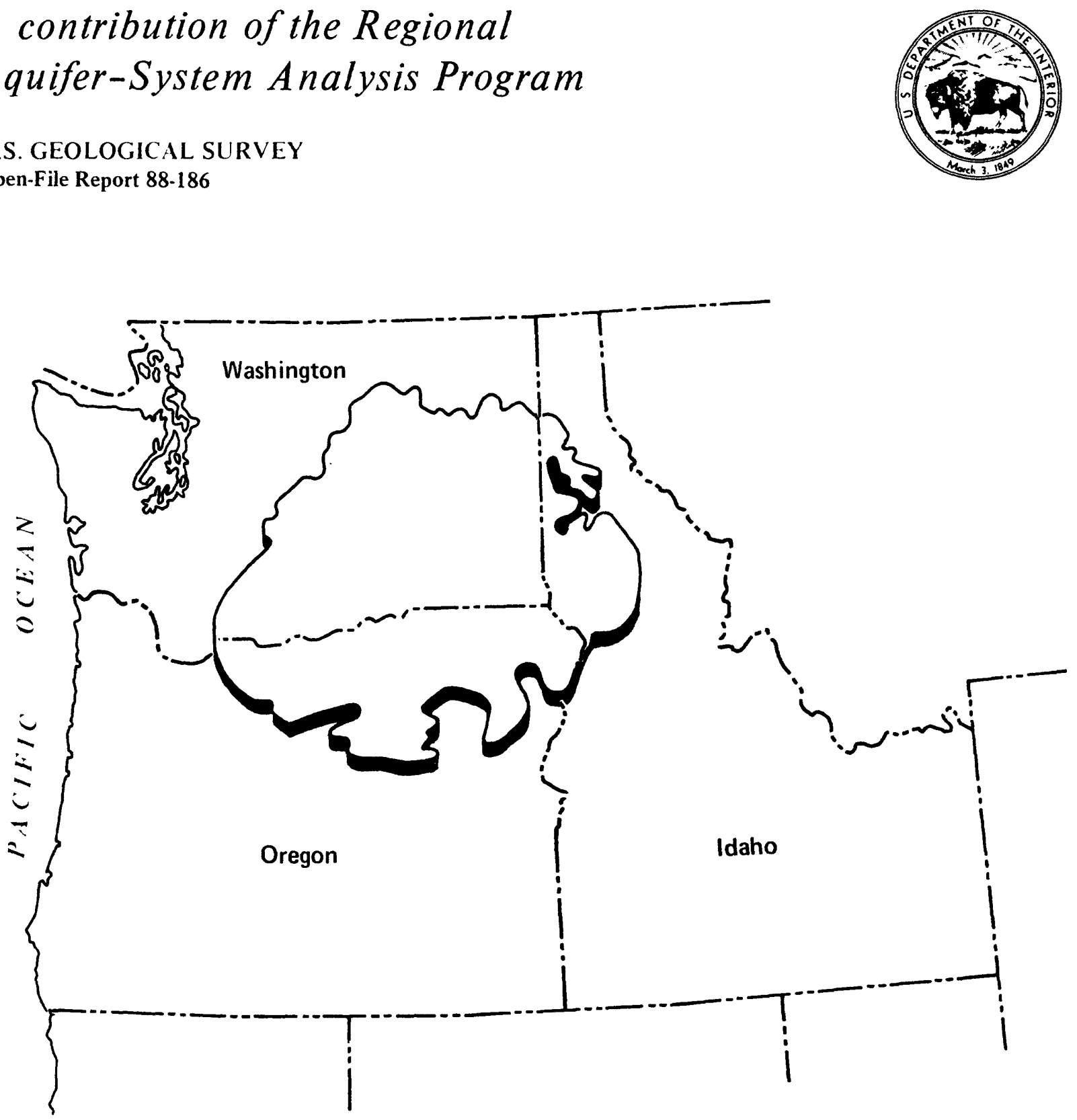
DEPARTMENT OF THE INTERIOR

MANUEL LUJAN, JR., Secretary

U.S. GEOLOGICAL SURVEY

Dallas L. Peck, Director

For additional information write to:

District Chief

U.S. Geological Survey 1201 Pacific Avenue, Suite 600 Tacoma, Washington 98402-4384
Copies of this report may be purchased from:

U.S. Geological Survey Books and Open-File Reports Section Federal Center, BOX 25425

Denver, Colorado 80225 
ARCHIVING OF DEEP PERCOLATION MODELS, DATA FILES, AND CALCULATED RECHARGE ESTIMATES FOR THE COLUMBIA PLATEAU REGIONAL AQUIFER SYSTEM, WASHINGTON, OREGON, AND IDAHO

By J. J. Vaccaro and H. H. Bauer

U.S. GEOLOGICAL SURVEY

Open-File Report $88-186$

A Contribution of the Regional Aquifer-System Analysis Program

Tacoma, Washington

1990

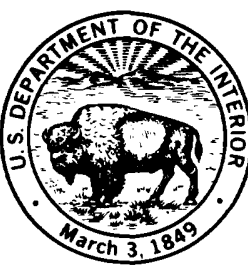


Abstract-1..

Introduction-1..

Magnetic tape attributes-... 2

Source code files for deep percolation model-_... 8

Data files-......... 9

Main data stream input..... 10

Model grid definition data-..... 10

Line printer output-map data-10

Soil type data-... 10

Land-use data-.... 10

Annual irrigation application rates-... 11

Land-surface altitude, slope, and aspect-...... 11

Annual average precipitation-1. 11

Daily discharge data-1 11

Monthly ground-water baseflow-... 11

Location of precipitation weather sites-... 12

Location and altitude of air temperature weather sites-1...-. 12

Long-term average July air temperatures-..... 12

Mean daily precipitation-... 12

Mean daily maximum air temperature-... 12

Mean daily minimum air temperature-...... 12

Inverse Lambert projection source code-1... 13

Model output-_..-_.

References-_... 13

\section{ILLUSTRATIONS}

Page

FIGURE 1. Map showing location of Columbia Plateau regional

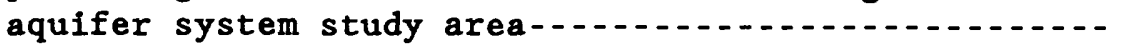

2. Map showing the zones, with reference numbers, where recharge was computed using the daily deep percolation model

TABLES

TABLE 1. Attributes for the zones which were modeled-1....... 5

2. List of files stored on magnetic tape-1. 6

3. Model reference numbers for the magnetic tape

files for a specific model zone-.. 8 
ARCHIVING OF DEEP PERCOLATION MODELS, DATA FILES, AND CALCULATED RECHARGE ESTIMATES FOR THE COLUMBIA PLATEAU REgIONAL AQUIFER SYSTEM, WASHINGTON, OREGON, AND IDAHO

By J. J. Vaccaro and H. H. Bauer

\begin{abstract}
The report documents the archiving of computer files used in a daily deep percolation model to calculate recharge estimates for the Columbia Plateau regional aquifer system in parts of Washington, Oregon, and Idaho. The files are obtainable on magnetic tape from the U.S. Geological Survey. There are 53 files containing source codes of the models used for 53 zones and one file containing the source code for an inverse Lambert projection. Basic input data and model output are each contained in 103 files, 53 files for predevelopment and 50 files for current land-use conditions. Other files contain data for (1) model grid definition; (2) line printer output-map configurations; (3) soll types; (4) land uses; (5) annual irrigation application rates; (6) land-surface altitudes, slopes, and aspects; (7) annual average precipitation values; (8) daily stream discharges; (9) monthly estimates of baseflow to streams; (10) locations of precipitation weather stations; (11) locations and altitudes of temperature weather stations; (12) long-term average July minimum and maximum air temperatures at temperature weather stations; (13) mean daily precipitation data at 103 weather stations for 22 years; (14) mean daily maximum air temperatures at 89 weather sites for 22 years; and (15) mean daily minimum air temperatures at 89 sites for 22 years.
\end{abstract}


A study of the Columbia Plateau regional aquifer system was begun in October 1982, as one of the 28 studies in the U.S. Geological Survey's Regional Aquifer-System Analyses Program (RASA). The Columbia Plateau aquifer system underlies the Columbia Plateau (fig. 1) in central and eastern Washington, north-central and eastern Oregon, and a small part of northwestern Idaho. The aquifer system is composed of the Columbia River Basalt Group, all of the intercalated sediments collectively assigned to the Ellensburg Formation, and the unconsolidated sediments overlying the basalts.

Recharge to the water table aquifer was estimated using a deep percolation mode1 (DPM), documented by Bauer and Vaccaro (1987), for the part of the aquifer system within the boundaries of a ground-water flow model being constructed for the study ( $\mathrm{fig}$. 2). The model was used to estimate recharge for 53 basins and zones, herein called zones (fig. 2), for predevelopment land-use conditions and for 50 zones for current land-use conditions. Landuse conditions in three zones (4, 5, and 37) remained unchanged as of 1977. The application of the DPM to these zones, including tables of characteristics and results, is given by Bauer and Vaccaro (1990). Attributes, including naming conventions and characteristics, for the 53 zones modeled are given in table 1 of this report.

The purpose of this report is to describe the archiving of the computer files containing DPM source code for each recharge model, the input data files and output file for each model, and a source code for an inverse Lambert projection. There are 775 files stored on magnetic tape at the U.S. Geological Survey's Washington State office, Tacoma, Washington. A 1isting of these files and the reference number of the modeled zone (fig. 2 and table 1) are given in table 2 , and the next section describes the attributes for the magnetic tape. Coples of the tape can be obtained from the state office Chlef, Water Resources Division, U.S. Geological Survey, Sulte 600, 1201 Pacific Avenue, Tacoma, Washington, 98402.

\section{MAGNETIC TAPE ATTRIBUTES}

The attributes of the magnetic tape for archiving the files described in this report are:

Fixed Record Length: Files 1 through 604, Files 605 through 626,

Files 627 through 670 ,

Files 671 through 774,

80 bytes

618 bytes

712 bytes

80 bytes

Block Size: Files 1 through $604,12,000$ bytes

Files 605 through 626, 11,742 bytes

Files 627 through 670, 12,104 bytes

File $671 \quad 1,360$ bytes

Files 672 through 774, 7,200 bytes 


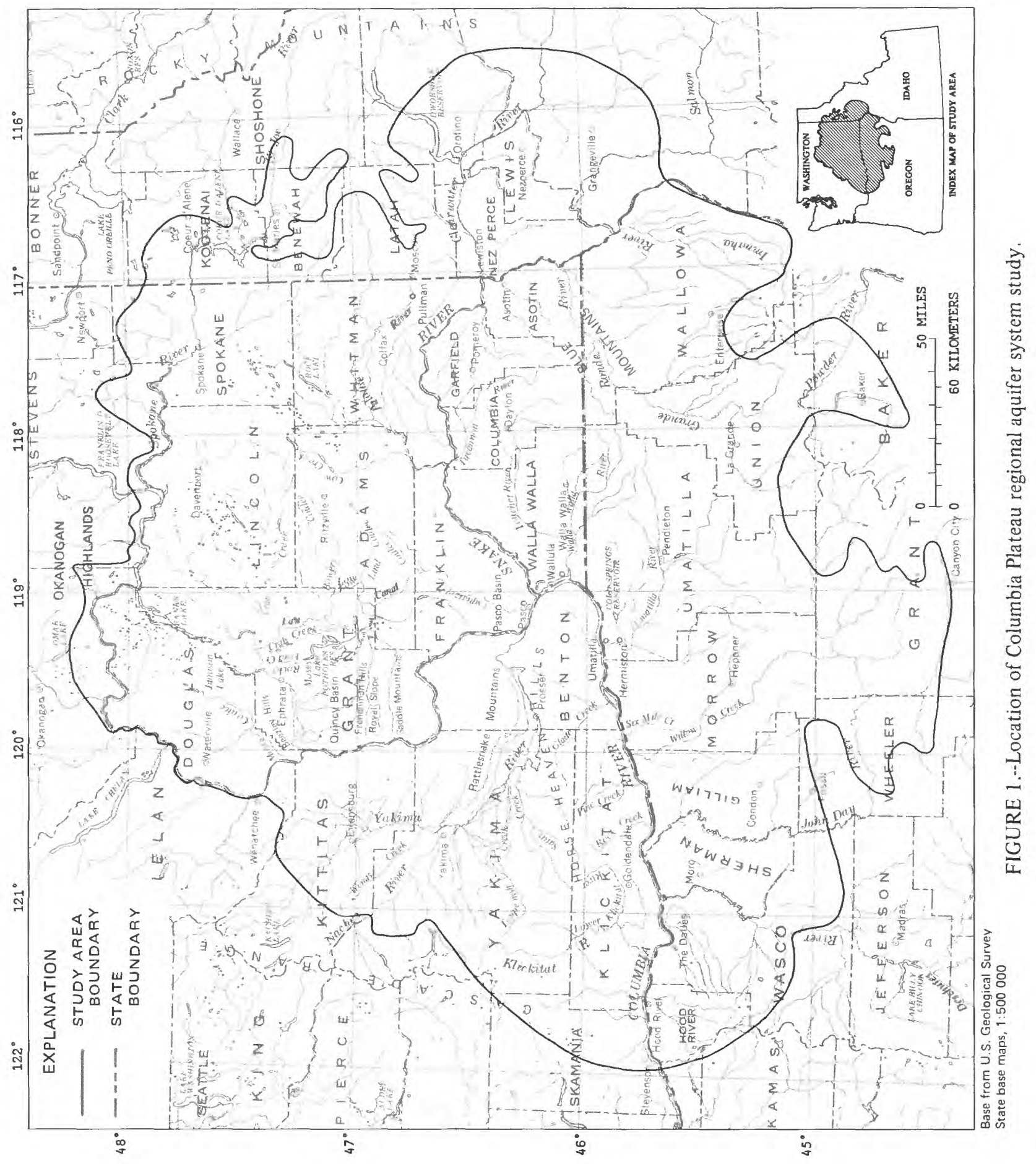




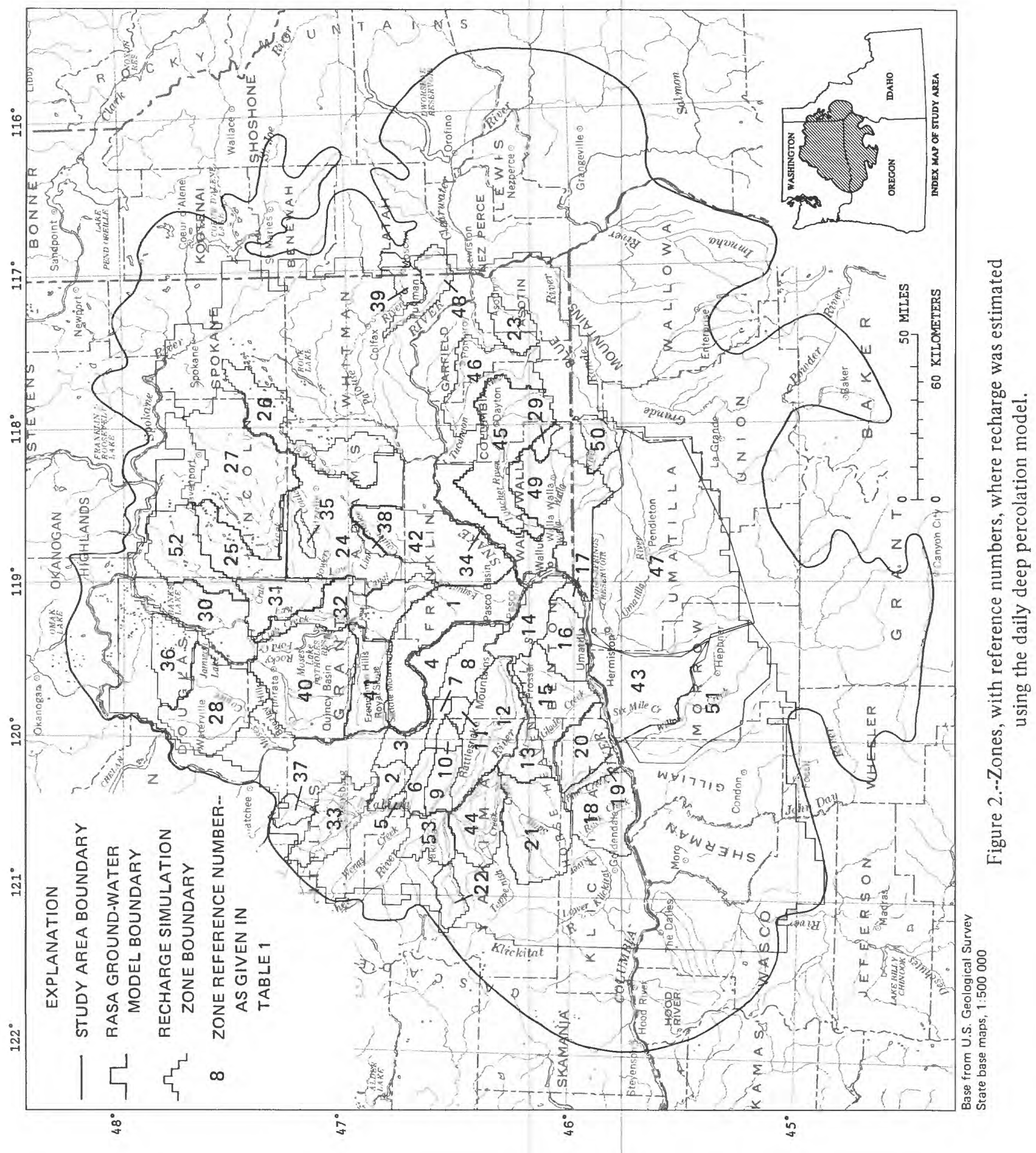


TABLE 1.--Attributes for the zones which were modeled

\begin{tabular}{|c|c|c|c|c|c|c|c|c|c|c|c|}
\hline $\begin{array}{l}\text { Refer- } \\
\text { ence } \\
\text { number }\end{array}$ & Name ${ }^{1}$ & $\begin{array}{l}\text { Average } \\
\text { latitude }\end{array}$ & $\begin{array}{c}\text { Area, in } \\
\text { square } \\
\text { miles } \\
\end{array}$ & $\begin{array}{l}\text { Years }^{2} \text { of } \\
\text { simulation }\end{array}$ & $\begin{array}{l}\text { Runoff } \\
\text { record }\end{array}$ & $\begin{array}{l}\text { Alti- } \\
\text { tude } 4 \\
\text { data }\end{array}$ & Nodes & Colls & $\begin{array}{l}\text { Cell size, } \\
\text { in square } \\
\text { miles }\end{array}$ & $\begin{array}{l}\text { Dry } \\
\text { land } 6 \\
\text { cells }\end{array}$ & $\begin{array}{l}\text { Irri- } \\
\text { gated } \\
\text { cells } \\
\end{array}$ \\
\hline 1 & BWIP1 & 46.5 & 737 & $1956-77$ & N & $\mathbf{Y}$ & 3,151 & 2,949 & 0.25 & 169 & 1,191 \\
\hline 2 & BWIP2 & 46.8 & 115 & $56-76$ & $\mathbf{P}$ & $\mathbf{Y}$ & 365 & 310 & .375 & 0 & 3 \\
\hline 3 & BWIP3 & 46.8 & 146 & $56-77$ & N & $\mathbf{Y}$ & 469 & 395 & .375 & 0 & 5 \\
\hline 4 & BWIP4 & 46.6 & 190 & $56-77$ & $N$ & $\mathbf{Y}$ & 581 & 507 & .375 & 0 & 0 \\
\hline 5 & BWIP5 & 46.8 & 20 & $56-77$ & $N$ & $\mathbf{Y}$ & 73 & 54 & .375 & 0 & 0 \\
\hline 6 & BWIP6 & 46.7 & 112 & $56-73$ & $\mathbf{P}$ & $\mathbf{Y}$ & 357 & 303 & .375 & 0 & 5 \\
\hline 7 & BWIP7 & 46.7 & 59 & $67-78$ & $\mathbf{P}$ & $\mathbf{Y}$ & 193 & 156 & .375 & 11 & 0 \\
\hline 8 & BWIP8 & 46.5 & 234 & $56-77$ & $\mathbf{N}$ & $\mathbf{Y}$ & 718 & 632 & .375 & 7 & 12 \\
\hline 9 & BWIP9 & 46.6 & 161 & $63-76$ & $\mathbf{P}$ & $\mathbf{Y}$ & 492 & 436 & .375 & 30 & 90 \\
\hline 10 & BWIP10 & 46.6 & 56 & $56-77$ & N & $Y$ & 181 & 149 & .375 & 38 & 0 \\
\hline 11 & BWIP11 & 46.5 & 52 & $56-77$ & N & $Y$ & 173 & 138 & .375 & 22 & 0 \\
\hline 12 & BWIP12 & 46.3 & 548 & $56-76$ & $\mathbf{P}$ & $\mathbf{Y}$ & 1,579 & 1.462 & .375 & 214 & 733 \\
\hline 13 & BWIP13 & 46.2 & 211 & $56-77$ & $\mathbf{N}$ & $\mathbf{Y}$ & 671 & 571 & .375 & 60 & 141 \\
\hline 14 & BWIP14 & 46.2 & 260 & $56-73$ & $\mathbf{P}$ & $\mathbf{Y}$ & 790 & 701 & .375 & 239 & 123 \\
\hline 15 & BWIP15 & 46.1 & 431 & $63-68$ & $\mathbf{s}$ & $\mathbf{Y}$ & 1,266 & 1,149 & .375 & 854 & 102 \\
\hline 16 & BWIP16 & 46.0 & 260 & $56-77$ & N & $Y$ & 760 & 692 & .375 & 215 & 94 \\
\hline 17 & BWIP17 & 46.0 & 52 & $56-77$ & $\mathbf{N}$ & $\mathbf{Y}$ & 176 & 139 & .375 & 68 & 26 \\
\hline 18 & BWIP18 & 46.8 & 391 & $63-68$ & D & $\mathbf{Y}$ & 1,665 & 1,565 & .25 & 179 & 14 \\
\hline 19 & BWIP19 & 45.8 & 70 & $64-68$ & $\mathbf{s}$ & $\mathbf{Y}$ & 352 & 278 & .25 & 40 & 0 \\
\hline 20 & BWIP20 & 45.9 & 281 & $63-68$ & D & $Y$ & 1,218 & 1,124 & .25 & 257 & 58 \\
\hline 21 & BWIP21 & 46.2 & 576 & $63-72$ & D & $Y$ & 1,532 & 1,537 & .375 & 1 & 4 \\
\hline 22 & Ahtanum & 46.5 & 122 & $61-67$ & D & $\mathbf{Y}$ & 552 & 487 & .25 & 2 & 17 \\
\hline 23 & Asotin & 46.23 & 157 & $60-77$ & D & $\mathbf{Y}$ & 204 & 167 & 1.0 & 30 & 0 \\
\hline 24 & Bowers Coulee & 47.0 & 1,020 & $56-76$ & $\mathbf{s}$ & N & 1,134 & 1,020 & 1.0 & 758 & 150 \\
\hline 25 & Canniwai & 47.5 & 347 & $56-77$ & $\mathbf{N}$ & N & 442 & 347 & 1.0 & 117 & 67 \\
\hline 26 & Cow Creek & 47.2 & 546 & $62-69$ & D & N & 657 & 546 & 1.0 & 161 & 35 \\
\hline 27 & Crab Creek & 47.45 & 1,019 & $56-77$ & D & N & 1,126 & 1,019 & 1.0 & 612 & 31 \\
\hline 28 & Douglas Creek & 46.6 & 601 & $56-77$ & D & $\mathbf{Y}$ & 672 & 601 & 1.0 & 406 & 15 \\
\hline 29 & Dry Creek & 46.15 & 57 & $56-66$ & D & $\mathbf{Y}$ & 226 & 182 & .25 & 125 & 0 \\
\hline 30 & East Banks & 47.5 & 482 & $56-77$ & N & $\mathbf{N}$ & 550 & 482 & 1.0 & 222 & 41 \\
\hline 31 & East High Canal & 47.3 & 293 & $56-77$ & N & $\mathbf{N}$ & 346 & 293 & 1.0 & 69 & 105 \\
\hline 32 & Eastlow Canal & 47.00 & 504 & $56-77$ & N & $N$ & 599 & 504 & 1.0 & 18 & 266 \\
\hline 33 & Ellensburs & 47.0 & 362 & $56-77$ & N & $N$ & 425 & 362 & 1.0 & 3 & 193 \\
\hline 34 & Eureka Flat & 46.35 & 501 & $56-77$ & $\mathbf{N}$ & $\mathbf{N}$ & 501 & 409 & 1.0 & 240 & 68 \\
\hline 35 & Farrier Coulee & 47.15 & 43 & $62-73$ & D & $\mathbf{N}$ & 217 & 172 & .25 & 148 & 16 \\
\hline 36 & Jameson Lake & 47.7 & 293 & $56-77$ & N & $\mathbf{N}$ & 338 & 293 & 1.0 & 179 & 0 \\
\hline 37 & Naneum Creek & 47.2 & 85 & $57-77$ & $\mathbf{s}$ & $\mathbf{Y}$ & 390 & 338 & .25 & 0 & 0 \\
\hline 38 & Providence Coulee & 46.9 & 31 & $56-76$ & D & N & 162 & 122 & .25 & 73 & 36 \\
\hline 39 & Pullman-Moscow & 46.7 & 106 & $60-77$ & D & $\mathbf{Y}$ & 592 & 525 & .25 & 430 & 0 \\
\hline 40 & Quincy & 47.1 & 872 & $56-77$ & $\mathbf{N}$ & $\mathbf{Y}$ & 945 & 872 & 1.0 & 69 & 314 \\
\hline 41 & Royal Slope & 46.9 & 321 & $56-77$ & N & $\mathbf{Y}$ & 1,396 & 1,285 & .25 & 134 & 470 \\
\hline 42 & Rye Grass Flat & 46.65 & 711 & $56-77$ & N & N & 787 & 711 & 1.0 & 496 & 47 \\
\hline 43 & Six Mile Creek & 45.6 & 624 & $56-77$ & $\mathbf{N}$ & $\mathbf{N}$ & 35 & 24 & $\mathrm{v}$ & 0 & 3 \\
\hline 44 & Toppentsh & 46.4 & 346 & $56-77$ & $N$ & $N$ & 397 & 346 & 1.0 & 40 & 213 \\
\hline
\end{tabular}


TABLE 1.--Attributes for the zones which were modeled--continued

\begin{tabular}{|c|c|c|c|c|c|c|c|c|c|c|c|}
\hline $\begin{array}{l}\text { Refer- } \\
\text { ence } \\
\text { number }\end{array}$ & $\mathrm{Name}^{1}$ & $\begin{array}{l}\text { Average } \\
\text { latitude }\end{array}$ & $\begin{array}{l}\text { Area, in } \\
\text { square } \\
\text { miles }\end{array}$ & $\begin{array}{l}\text { Years } 2 \text { of } \\
\text { simulation }\end{array}$ & $\begin{array}{l}\text { Runoff } \\
\text { record }\end{array}$ & $\begin{array}{l}\text { Alti- } \\
\text { tudo } 4 \\
\text { data } \\
\end{array}$ & Nodes & CeIls & $\begin{array}{c}\text { Cell size, } \\
\text { in square } \\
\text { miles }\end{array}$ & $\begin{array}{l}\text { Dry } \\
\text { land } 6 \\
\text { cells }\end{array}$ & $\begin{array}{l}\text { Irri- } \\
\text { gated } \\
\text { cells } \\
\end{array}$ \\
\hline 45 & Touchet River & 46.30 & 734 & $56-77$ & D & $\mathbf{Y}$ & 835 & 734 & 1.0 & 543 & 9 \\
\hline 46 & Toucannon River & 46.40 & 433 & $59-77$ & D & $\mathbf{Y}$ & 515 & 433 & 1.0 & 197 & 0 \\
\hline 47 & Umatilla River & 45.55 & 2,392 & $56-77$ & $\mathbf{s}$ & $\mathbf{Y}$ & 143 & 120 & $\mathbf{v}$ & 39 & 22 \\
\hline 48 & Union Flat Creok & 46.6 & 185 & $56-70$ & D & N & 239 & 185 & 1.0 & 113 & 0 \\
\hline 49 & Walla Walla & 46.0 & 726 & $56-77$ & $N$ & N & 814 & 726 & 1.0 & 508 & 115 \\
\hline \multirow[t]{2}{*}{50} & South-North Fork & & & & & & & & & & \\
\hline & Wa1la Wa1la River & 45.85 & 128 & $56-77$ & $D, S$ & $\mathbf{Y}$ & 581 & 513 & .25 & 8 & 6 \\
\hline 51 & Willow Creek & 45.4 & 856 & $56-77$ & $\mathbf{N}$ & $\mathbf{Y}$ & 85 & 64 & $\mathbf{v}$ & 0 & 11 \\
\hline 52 & Wilson Creek & 47.7 & 427 & $56-72$ & D & $\mathbf{Y}$ & 494 & 427 & 1.0 & 288 & 21 \\
\hline 53 & Yakima & 46.6 & 203 & $56-77$ & $\mathbf{N}$ & $\mathbf{N}$ & 246 & 203 & 1.0 & 10 & 110 \\
\hline
\end{tabular}

${ }^{1}$ Name refers to location of zone or feature within area and BWIP refers to zones in the Basalt Waste Isolation Project study area discussed in Bauer and Vaccaro (1987).

2 Years is the calendar years for which the model was operated.

${ }^{3}$ Runoff record shows the type of streamflow data used in the model, where: $N=$ assumed no surface runoff, $\mathrm{D}=$ observed daily values, $\mathrm{S}=$ synthesized record using standard techniques, and $\mathrm{P}=\mathrm{daily}$ values synthesized from peak value data.

$4=a 11$ cells for zone that had altitude, slope, and aspect data; N=none of the cells had such data.

${ }^{5}$ Size of cells that zones were subdivided into, and Vrvariable size blocks.

${ }^{6}$ Number of cells in a zone that had dryland agriculture assumed to be winter wheat on 2-year cycle.

TABLE 2.--List of files stored on magnetic tape

File Numbers Contents

Source code for DPM models
Main data stream input
$107-156^{2}$


TABLE 2.--List of files stored on magnetic tape--continued

File Numbers

Contents

Land-use classification data for current land-use conditions
Annul irrigation application rates (in inches) for current
$419-458^{3}$

Then follows the longitude, latitude, and altitude (in feet) of 89 air temperature weather sites

604 Long-term average July minimum and maximum air temperatures at 89 weather sites

$605-626$

ANSI standard direct access files for mean daily precipitation at 103 weather sites, each file is one calendar year starting in 1956.

627-648 ANSI standard direct access files for mean daily maximum air temperatures at 89 weather sites

649-670 ANSI standard direct access files for mean daily minimum air temperatures at 89 weather sites

671

Source code for an inverse Lambert projection, converts feet to decimal degrees

$672-724^{1}$

Results of operating the models for predevelopment land-use conditions (model output)

$725-774^{2}$

Results of operating the models for current land-use conditions (model output)

${ }^{1}$ Files in same order as reference numbers in table 1.

${ }^{2}$ Files in same order as reference numbers in table 1 except zones 4, 5, and 37 not included, because not modeled for current land-use conditions.

${ }^{3}$ Order of files listed in table 3. 
The FORTRAN 77 source code for each of the 53 DPMs is stored on magnetic tape as an ASCII file, and the file numbers are listed on tables 2 and 3 .

Each file consists of the MAIN program and the subroutines. The dimensions in the common blocks are unique for each model and, in fact, are the only change in the source code for each model.

TABLE 3.--Model reference numbers for the magnetic tape files for a specific model zone

\begin{tabular}{|c|c|c|c|c|c|c|c|c|c|c|c|c|c|}
\hline $\begin{array}{l}\text { Model } \\
\text { refer- } \\
\text { ence } \\
\text { number }\end{array}$ & $\begin{array}{l}\text { Source } \\
\text { codes } \\
\end{array}$ & $\begin{array}{r}\mathrm{Ma} \\
\mathrm{da} \\
\text { str } \\
\mathrm{p}\end{array}$ & $\begin{array}{l}\text { in } \\
\text { ta } \\
\frac{\text { eam }}{c} \\
\end{array}$ & $\begin{array}{c}\text { Grid } \\
\text { defin1- } \\
\text { tion } \\
\end{array}$ & $\begin{array}{c}\text { Line } \\
\text { printer } \\
\text { output- } \\
\text { map } \\
\end{array}$ & $\begin{array}{l}\text { Soil } \\
\text { type }\end{array}$ & & $\frac{\text { use }}{\mathrm{I}}$ & $\begin{array}{l}\text { Annual } \\
\text { irriga- } \\
\text { tion } \\
\text { rates } \\
\end{array}$ & $\begin{array}{c}\text { Land- } \\
\text { surface } \\
\text { data } \\
\end{array}$ & $\begin{array}{l}\text { Annual } \\
\text { average } \\
\text { precipi- } \\
\text { tation } \\
\end{array}$ & $\begin{array}{c}\text { Daily } \\
\text { dis- } \\
\text { charge } \\
\end{array}$ & $\begin{array}{l}\text { Monthly } \\
\text { ground- } \\
\text { water } \\
\text { baseflow }\end{array}$ \\
\hline 1 & 1 & 54 & 107 & 157 & 210 & 263 & 316 & 369 & 419 & 459 & 494 & --- & -- \\
\hline 2 & 2 & 55 & 108 & 158 & 211 & 264 & 317 & 370 & 420 & 460 & 495 & 547 & 575 \\
\hline 3 & 3 & 56 & 109 & 159 & 212 & 265 & 318 & 371 & 421 & 461 & 496 & --- & --- \\
\hline 4 & 4 & 57 & -.- & 160 & 213 & 266 & 319 & --- & -.- & 462 & 497 & --- & --- \\
\hline 5 & 5 & 58 & -- & 161 & 214 & 267 & 320 & -- & $\cdots$ & 463 & 498 & -- & $\cdots$ \\
\hline 6 & 6 & 59 & 110 & 162 & 215 & 268 & 321 & 372 & 422 & 464 & 499 & 548 & 576 \\
\hline 7 & 7 & 60 & 111 & 163 & 216 & 269 & 322 & 373 & -- & 465 & 500 & 549 & 577 \\
\hline 8 & 8 & 61 & 112 & 164 & 217 & 270 & 323 & 374 & 423 & 466 & 501 & --- & -.- \\
\hline 9 & 9 & 62 & 113 & 165 & 218 & 271 & 324 & 375 & 424 & 467 & 502 & 550 & 578 \\
\hline 10 & 10 & 63 & 114 & 166 & 219 & 272 & 325 & 376 & --- & 468 & 503 & --- & $-\cdots$ \\
\hline 11 & 11 & 64 & 115 & 167 & 220 & 273 & 326 & 377 & -- & 469 & 504 & -.- & -.. \\
\hline 12 & 12 & 65 & 116 & 168 & 221 & 274 & 327 & 378 & 425 & 470 & 505 & 551 & 579 \\
\hline 13 & 13 & 66 & 117 & 169 & 222 & 275 & 328 & 379 & 426 & 471 & 506 & --- & -.. \\
\hline 14 & 14 & 67 & 118 & 170 & 223 & 276 & 329 & 380 & 427 & 472 & 507 & 552 & 580 \\
\hline 15 & 15 & 68 & 119 & 171 & 224 & 277 & 330 & 381 & 428 & 473 & 508 & 553 & 581 \\
\hline 16 & 16 & 69 & 120 & 172 & 225 & 278 & 331 & 382 & 429 & 474 & 509 & -.- & -- \\
\hline 17 & 17 & 70 & 121 & 173 & 226 & 279 & 332 & 383 & 430 & 475 & 510 & --- & -.- \\
\hline 18 & 18 & 71 & 122 & 174 & 227 & 280 & 333 & 384 & 431 & 476 & 511 & 554 & 582 \\
\hline 19 & 19 & 72 & 123 & 175 & 228 & 281 & 334 & 385 & $-\cdots$ & 477 & 512 & 555 & 583 \\
\hline 20 & 20 & 73 & 124 & 176 & 229 & 282 & 335 & 386 & 432 & 478 & 513 & 556 & 584 \\
\hline 21 & 21 & 74 & 125 & 177 & 230 & 283 & 336 & 387 & 433 & 479 & 514 & 557 & 585 \\
\hline 22 & 22 & 75 & 126 & 178 & 231 & 284 & 337 & 388 & 434 & 480 & 515 & 558 & 586 \\
\hline 23 & 23 & 76 & 127 & 179 & 232 & 285 & 338 & 389 & --- & 481 & 516 & 559 & 587 \\
\hline 24 & 24 & 77 & 128 & 180 & 233 & 286 & 339 & 390 & 435 & --- & 517 & 560 & 588 \\
\hline 25 & 25 & 78 & 129 & 181 & 234 & 287 & 340 & 391 & 436 & -- & 518 & --- & --- \\
\hline 26 & 26 & 79 & 130 & 182 & 235 & 288 & 341 & 392 & 437 & -.- & 519 & 561 & 589 \\
\hline 27 & 27 & 80 & 131 & 183 & 236 & 289 & 342 & 393 & 438 & --- & 520 & 562 & 590 \\
\hline 28 & 28 & 81 & 132 & 184 & 237 & 290 & 343 & 394 & 439 & 482 & 521 & 563 & 591 \\
\hline 29 & 29 & 82 & 133 & 185 & 238 & 291 & 344 & 395 & -- & 483 & 522 & 564 & 592 \\
\hline 30 & 30 & 83 & 134 & 186 & 239 & 292 & 345 & 396 & 440 & --- & 523 & -.. & -.- \\
\hline 31 & 31 & 84 & 135 & 187 & 240 & 293 & 346 & 397 & 441 & --- & 524 & --- & -- \\
\hline 32 & 32 & 85 & 136 & 188 & 241 & 294 & 347 & 398 & 442 & -- & 525 & -- & $-\cdots$ \\
\hline 33 & 33 & 86 & 137 & 189 & 242 & 295 & 348 & 399 & 443 & $\cdots$ & 526 & --. & -.. \\
\hline 34 & 34 & 87 & 138 & 190 & 243 & 296 & 349 & 400 & 444 & --- & 527 & --- & $\cdots$ \\
\hline 35 & 35 & 88 & 139 & 191 & $2 / 4$ & 297 & 350 & 401 & 445 & --- & 528 & 565 & 593 \\
\hline 36 & 36 & 89 & 140 & 192 & 245 & 298 & 351 & 402 & -- & -- & 529 & --- & -.- \\
\hline 37 & 37 & 90 & --- & 193 & 246 & 299 & 352 & -- & -- & 484 & 530 & 566 & 594 \\
\hline
\end{tabular}


TABLE 3.--Model reference numbers for the magnetic tape files for a specific model zone--continued

\begin{tabular}{|c|c|c|c|c|c|c|c|c|c|c|c|c|c|}
\hline $\begin{array}{l}\text { Model } \\
\text { refer- } \\
\text { ence } \\
\text { number }\end{array}$ & $\begin{array}{l}\text { Source } \\
\text { codes } \\
\end{array}$ & $\begin{array}{r}M a \\
d a \\
\text { str } \\
1 \\
\end{array}$ & $\begin{array}{l}\text { in } \\
\frac{\text { ta }}{c} \\
\frac{c}{c}\end{array}$ & $\begin{array}{l}\text { Grid } \\
\text { defini- } \\
\text { tion } \\
\end{array}$ & $\begin{array}{l}\text { Line } \\
\text { printer } \\
\text { output- } \\
\text { map } \\
\end{array}$ & $\begin{array}{l}\text { Soil } \\
\text { type }\end{array}$ & $\frac{\text { Land }}{1}$ & $\frac{\text { use }}{\mathrm{I}}$ & $\begin{array}{l}\text { Annual } \\
\text { irriga- } \\
\text { tion } \\
\text { rates } \\
\end{array}$ & $\begin{array}{c}\text { Land- } \\
\text { surface } \\
\text { data } \\
\end{array}$ & $\begin{array}{l}\text { Annual } \\
\text { average } \\
\text { precipi- } \\
\text { tation } \\
\end{array}$ & $\begin{array}{c}\text { Daily } \\
\text { dis- } \\
\text { charge }\end{array}$ & $\begin{array}{l}\text { Monthly } \\
\text { ground- } \\
\text { water } \\
\text { baseflow }\end{array}$ \\
\hline 38 & 38 & 91 & 141 & 194 & 247 & 300 & 353 & 403 & 446 & -- & 531 & 567 & 595 \\
\hline 39 & 39 & 92 & 142 & 195 & 248 & 301 & 354 & 404 & --- & 485 & 532 & 568 & 596 \\
\hline 40 & 40 & 93 & 143 & 196 & 249 & 302 & 355 & 405 & 447 & 486 & 533 & -- & --- \\
\hline 41 & 41 & 94 & 144 & 197 & 250 & 303 & 356 & 406 & 448 & 487 & 534 & --- & -.- \\
\hline 42 & 42 & 95 & 145 & 198 & 251 & 304 & 357 & 407 & 449 & -- & 535 & --- & --- \\
\hline 43 & 43 & 96 & 146 & 199 & 252 & 305 & 358 & 408 & 450 & --- & 536 & --- & -- \\
\hline 44 & 44 & 97 & 147 & 200 & 253 & 306 & 359 & 409 & 451 & --- & 537 & --- & -- \\
\hline 45 & 45 & 98 & 148 & 201 & 254 & 307 & 360 & 410 & 452 & 488 & 538 & 569 & 597 \\
\hline 46 & 46 & 99 & 149 & 202 & 255 & 308 & 361 & 411 & --- & 489 & 539 & 570 & 598 \\
\hline 47 & 47 & 100 & 150 & 203 & 256 & 309 & 362 & 412 & 453 & 490 & 540 & 571 & 599 \\
\hline 48 & 48 & 101 & 151 & 204 & 257 & 310 & 363 & 413 & --- & --- & 541 & 572 & 600 \\
\hline 49 & 49 & 102 & 152 & 205 & 258 & 311 & 364 & 414 & 454 & -- & 542 & $\cdots$ & --- \\
\hline 50 & 50 & 103 & 153 & 206 & 259 & 312 & 365 & 415 & 455 & 491 & 543 & 573 & 601 \\
\hline 51 & 51 & 104 & 154 & 207 & 260 & 313 & 366 & 416 & 456 & 492 & 544 & -- & --- \\
\hline 52 & 52 & 105 & 155 & 208 & 261 & 314 & 367 & 417 & 457 & 493 & 545 & 574 & 602 \\
\hline 53 & 53 & 106 & 156 & 209 & 262 & 315 & 368 & 418 & 458 & --- & 546 & --- & --- \\
\hline
\end{tabular}

$1_{p}=$ Files are for predevelopment land-use conditions; $c=$ files are for current land-use conditions.

\section{DATA FILES}

The data needed for input to each DPM are stored on 618 magnetic tape files and have been grouped into 15 categorles. The data categories and pertinent information for each category are described in the subsections that follow. Many of the data in the files are for discrete rectangular areas called cells; the cells are the divisions of a modeled area for which the recharge calculations are made. A description and FORTRAN format for the data files used in each model are given by Bauer and Vaccaro (1987), and all file numbers and associated information are given in table 2. The input data files are set up to be used for either predevelopment or current land-use conditions (table 3). Generally, when a model that has been set up to operate under predevelopment land-use conditions is changed to operate under current landuse conditions, only the main data stream and the land-use file would change. Furthermore, a simulation for current land-use conditions might require annual average irrigation application rates. All longltude and latitude values are in decimal degrees. 


\section{Main Data Stream Input}

Files 54 through 156 contain the general information on the model setup that includes such items as years of simulation, FORTRAN input and output device numbers, simulation options, and output options. These basic input data are currently set up to be read from FORTRAN unit number 5, defined as IN1 in the subroutine DATAIN. There are 103 data files representing 53 predevelopment-condition models and 50 current-condition mode1s.

\section{Mode1 Grid Definition Data}

Files 157 through 209 are the model grid definition files. The model grid data in these files establishes the cells for a modeled zone. The $x, y$ locations in each file are in Lambert feet. File 672, which is the source code for the inverse of the Lambert projection, can be used to convert the $x, y$ coordinates in Lambert feet to longitude and latitude (decimal degrees).

\section{Line Printer Output-Map Data}

Files 210 through 262 are the data that define how the estimates of recharge and actual evapotranspiration, stored in one-dimensional arrays, will be printed in two dimensions for a modeled area. These files are integer data relating array sequence to row-column position.

\section{So1l Type Data}

Files 263 through 315 are integer arrays of soll number codes assigned to each cell of a model. Each number refers to a particular combination of soil properties defined in the main data input stream (files 54 through 156).

\section{Land-Use Data}

Files 316 through 418 are integer arrays of land-use number codes for predevelopment and current conditions. Each integer represents the prevalling land use for a model cell that corresponds to one of the land uses described by Bauer and Vaccaro (1987). 


\section{Annual Irrigation Application Rates}

The first record in each of files 419 through 458 contains an integer number equal to the total number of cells in a zone with irrigation. The following records (equal to number of cells with irrigation) have cell number and annual application rate (In inches per year). There are 40 zones that have irrigated cells. The reference number of the model zone assoclated with the file number is given in table 3 .

\section{Land-Surface Altitude, Slope, and Aspect}

Each record in files 459 through 493 contains a cell number and the altitude, slope, and aspect for that cell. Table 3 defines which of the 35 model zones with land-surface information is associated with the file number.

These data, excluding cell numbers, were read as unformatted data off of a FORTRAN unit number different than IN $1=5$ (see beginning of this section). The data have been prefixed with a cell number, formatted, and then put into the tape files in order to make them machine readable. Thus, either these data files will need to be processed into unformatted files or the main data stream will have to be changed in order to operate the models (see Bauer and Vaccaro, 1987).

\section{Annua1 Average Precipitation}

Files 494 through 546 contain the long-term 22-year annual average precipitation data for each cell in a model. The precipitation data are in inches per year.

\section{Daily Discharge Data}

Files 547 through 574 contain daily stream discharge data for 28 of the model zones. The first record of each file contains the drainage area to the stream gage (square miles) and response time (days). Each record, thereafter, has one value of average daily streamflow (cubic feet per second). Table 3 gives the reference number of the model zone assoclated with the file number.

\section{Monthly Ground-Water Baseflow}

Files 575 through 602 contain estimates of mean monthly ground-water baseflow contribution to stream discharge, for each year simulated by a model. The 20 files are stored on tape in the same order as the discharge data discussed above (table 3 ). The estimates are in cubic feet per second, 12 values per record, one record per year. 


\section{Location of Precipitation Weather Sites}

The longitude and latitude of the 103 precipitation weather sites used for the study are listed in File 603.

\section{Location and Altitude of Air Temperature Weather Sites}

The longitude, latitude, and altitude (in feet) of the 89 temperature sites used in the study are contained in File 604.

\section{Long-term Average July Air Temperatures}

The 22-year long-term average July minimum and maximum air temperatures (in degrees Fahrenheit) for 89 weather sites are contained in File 552. These values are used in the calculation of potential evapotranspiration.

\section{Mean Daily Precipitation}

Files 606 through 627 contain ANSI standard direct access files for mean daily precipitation (integer values in inches times 100) for 103 weather sites. The files start with calendar year 1956 and end in calendar year 1977. Each record in a file has a record length of 309, which corresponds to 103 daily values for a particular day.

\section{Mean Daily Maximum Air Temperature}

Files 628 through 649 contain ANSI standard direct access files for mean daily maximum air temperature (in degrees Fahrenheit) for 89 weather sites, one file per calendar year starting with year 1956. Each record in a file has a record length of 356 , corresponding to 89 dally values for a day.

\section{Mean Daily Minimum Air Temperature}

Files 650 through 671 contain ANSI standard direct access files for mean daily minimum air temperature (in degrees Fahrenheit) for 89 weather sites, one file per calendar year starting with year 1956. Each record in a file has a record length of 356 , corresponding to 89 dally values for a day. 
File 672 contains the source code for a program to convert the $x, y$ location data (in Lambert feet) in files 157 through 209 to decimal degrees.

MODEL OUTPUT

Files 673 through 775 contain the DPM output from operating the 53 models (table 3). The first 53 files ( 673 through 725 ) are the output for predevelopment land-use conditions, and the last 50 files ( 726 through 775) are the DPM output for simulating deep percolation under current land-use conditions.

\section{REFERENCES}

Bauer, H. H., and Vaccaro, J. J., 1987, Documentation of a deep percolation model for estimating ground-water recharge: U.S. Geological Survey OpenFile Report 86-536, 140 p.

Bauer, H. H., and Vaccaro, J. J., 1990, Estimates of ground-water recharge to the Columbia Plateau regional aquifer system, Washington, Oregon, and Idaho, for predevelopment and current land-use conditions: U.S.

Geological Survey, Water-Resources Investigations Report 88-4108, 37 p. 